\title{
İRAN'DAN ANADOLU'YA SELÇUKLU PARALARI \\ (Selçuklu sikkelerinin özellikleri ve İran'dan Anadolu'ya görülen değişiklikler)
}

\section{ÖZET}

Bir Türk-İslam Devleti olan Büyük Selçuklu Devleti (Iran Selçukluları) ve onunla aynı aileden gelen, Kutalmışoğulları tarafından kurulan Anadolu Selçuklu Devleti (Türkiye Selçukluları), kültür ve medeniyet açısından birbirlerine çok benzerler. Ortaçağ devletlerinde, egemenliğin en önemli unsurlarından birisi paradır. Selçuklu sikkeleri, İran'dan Anadolu'ya, çeşitli kültür ve medeniyetlerin etkisi ile, önemli bir değişim süreci yaşamıştır. Bu makalede bu süreci özetlemeye çalıştık.

\section{ABSTRACT}

The Great Seljuk Empire, which was a Turkishİslamic State, and the Anatolian Seljuk State, which was established by the sons of Kutalmıs of the same family origin, are both similar to each other culturally and as a civilization. By the Middle Ages, one of the most important elements of sovereighnty was Money. Seljukian coins had gone through an important process of transformation by the influence of various cultures and civilizations all the way through İran and Anatolia. This study, we have tried to summarize this process.

\section{GİRIŞ̧}

Büyük Selçuklu Devleti'nin siyasî bakımdan egemenliği, 1040 Dandanakan Savaşı sonrasında ilan edilmiştir. Büyük Selçuklulara ait ilk sikke,Sultan Tuğrul Bey zamanında H.433 (M.10411042) de Nişapur şehrinde basıldı.Bu sikkede,çok belirgin bir şekilde İran (Samanî) ve Abbasî sikkelerinin etkileri görülmektedir.Bundan sonra kesilen Selçuklu sikkelerinde,motif ve süslemeler dışında,benzer özellikler devam etmiştir.Son Büyük Selçuklu sultanı Sancar'ın sikkelerinde,sadece sultana ait unvanların tamamen Türkçe unvanlar olduğu görülür.

\footnotetext{
* Atatürk Üniversitesi Kâzım Karabekir Eğitim Fakültesi İlköğretim Bölümü Sosyal Bilgiler Eğitimi Anabilim Dalı Öğretim Üyesi
} 
Anadolu Selçuklu Devleti'nde,ilk iki hükümdara ait (Kutalmışoğlu Süleyman Şah ve I.Kılıç Arslan) sikke bulunmamaktadır.Günümüzde mevcut olan Selçuklu sikkeleri kataloglarında,Anadolu Selçuklu Sultanlarına ait ilk sikke,sulat I.Mesud'a aittir.Bu sikkenin basım yeri ve basım tarihi siliktir.

Büyük Selçuklu sikkelerinde görülen Abbasî etkileri,Anadolu Selçuklu sikkelerinde yerini,İran ve Bizans etkilerine bırakmıştır. Anadolu sikkelerinde, Kuşan ve Akhun paralarında görülen Hurşit (güneş) ve Şir (arslan) motiflerinin yanı sıra, hükümdar portreleri de kullanılmıştır.

İslam Dininin,resmi yasakladığı iddialarına karşılık ,Selçuklu paralarında hükümdar portrelerinin kullanılması ilgi çekicidir.

Selçuklu paraları ile ilgili ilk önemli araştırmalar Stanley Lane Poole,Eduard von Zambaur, Markoff,Dominique Sourdel,N.W.Lowick,Ahmed Tevhid,Ahmed Ziya,Şerafettin Erel ve Coşkun Alptekin tarafindan yapıldı.̇llk önemli koleksiyonlar ise 1877 de Lane Poole ve 1896 da Markoff tarafindan yayınlandı.Günümüzde,Dünyanın en zengin Selçuklu paraları Koleksiyonu, İngiltere'de British Museum'da bulunmaktadır.Bu koleksiyonda Büyük Selçuklular, Suriye Selçukluları, Irak Selçukluları ve Kirman Selçuklularına ait 140 çeşit sikke bulunmaktadır.

\section{I-TÜRKLERDE PARA}

Para,orta çağın bütün toplumlarında,egemenliğin en önemli unsurlarından birisi olmuştur.

Orta çağın çok önemli bir sürecinde İran (Sasani) ve Bizans (DoğuRoma) medeniyetleri,etkin ve egemen bir konumda oldular.Özellikle Sasani ve Bizans paraları,günümüzdeki A.B.D. Doları ve A.B. EURO' su gibi,çok geniş bir kullanım alanı ve ekonomik güce sahip olmuşlardı. Bu iki siyasal ve ekonomik güç,çağdaşları olan bir çok komşu toplumu etkileyerek, hem siyasal kurum gelenekleri,hem de ekonomik kurum ve tarzlarının bu ülkeler tarafından benimsenmesi ve taklit edilmesine neden oldular.

$\mathrm{Bu}$ iki büyük devletten etkilenen toplumlar arasına V.yüzyıldan itibaren Türkler de katıldı. Kuşanlar,Akhunlar,Büyük Selçuklular (Íran Selçukluları) ,Türkiye Selçukluları ve Osmanlı Devleti, bunlardan bazılarıdır.

Türklerde paranın, bir ticarî değişim aracı olarak kullanılması,oldukça eskilere dayanır.

M.S.I.-III. yüzyıllar arasında Hindistan'ın kuzeyinde egemen olan Kuşanlar,madenî paralar kullandılar.İmparatorluk döneminde (Kanişka devri) bakır,gümüş ve altın paralar kullanan Kuşanlar,bu konuda Part 
(Iran)ve Grek (Büyük İskender'in Doğu Seferi esnasında Baktria 1denilen Kuzey Hindistan'ın bir bölümünde kurulan Eski Yunan medeniyeti) paralarını taklit ettiler.Kuşan paralarında , daha sonra Selçuklu ve diğer bazı Türk beyliklerinin paralarında görülen hilal,yıldız,hurşid (güneş) ve kurt motifleri ile; Doğu ve Güney Asya toplumlarının kültürlerinde önemli yeri olan deve ve Hint Öküzü motifleri bulunmaktadır.Kuşanlar bu motiflere sadece,kendi hükümdar damgaları ve isimlerini eklemişlerdi ${ }^{1}$.

III.yüzyılda Kuşan paralarında Hint ve Grek etkilerinin yerini Sasani etkileri aldi.

V.Yüzyıldan itibaren Kuşan topraklarına egemen olan Akhunlarda da belirgin bir şekilde Sasani etkileri görülmektedir.Akhun paralarında yıldız,hilal,hurşid gibi İran motifleri birlikte kurt ve dağ keçisi motifleri ağırlıktadır.Gümüş ve bakır olan Akhun paralarında, yönetici sülâlenin damgası,hükümdar portreleri ve isimleri yer almaktadır ${ }^{2}$.

Asya Hunları,mal değișiminin yanı sıra Çin paraları kullanmışlardır.Türgişlerin madeni paraları vardı.Bu paralarda özellikle arslan ongunu ve Türk damgası bulunurdu. ${ }^{3}$

Göktürkler zamanında kullanılan madeni paraların yazıları Çince ve Göktürkçe idi.Bu paralarda hükümdar ve hatun tasvirleri dikkat çekicidir. ${ }^{4}$

Uygurlarda,madeni paraların yanı sıra kâğıt paralar (Kaşgarlı Mahmud'a göre Kamdu denilen kumaş paralar)vardı.

Hazar Türkleri (Zekeriya El-Kazvinî'ye göre) kurşun paralar kullanırlardı.Bu paralar,Bağdat ölçüsüne göre 1 men (612 gram kurşun =1 dinar) yani 1 miskallik altın karşıllğı idiler. ${ }^{5}$

Kaşgarlı Mahmud'a göre Hazarlar, Ekin adı verilen ve 4 zira ${ }^{6}$ uzunlukta kumaş paralar kullanırlardı.

İslâmiyetin yayllmasından sonra,Müslüman $\quad$ Türk devletlerinde,egemenliğin en önemli iki unsuru "Hutbe ve Sikke" olmuştur.Müslüman Türk devletlerin ilk temsilcilerinden olan Karahanlılar,

\footnotetext{
${ }^{1}$ History of civilizations of Central Asia.vol.III.Ed.B.A.Litvinsky.v.d Unesco.1996

2 a.g.e

${ }^{3}$ ESİN.Emel, İslamiyetten Önce Türk Kültür Tarihi ve İslama Giriş. İstanbul 1978.s.140, L.XI.a.b.

${ }^{4}$ ESIN.Emel.a.g.e.Levha LX

${ }^{5} 1$ miskal $=1,5$ dirhem $=4.807$ gram.

${ }^{6} 1$ Zira $=24$ parmak $=75,35 \mathrm{~cm}$.
} 
İslâmiyeti kabul etmeden önce Uygur paralarının benzerlerini basmış ve kullanmışlardı.İslâmiyeti kabul ettikten sonra ,Abbasî ve İran paraları tarzında,gümüş ve bakır paralar bastılar. ${ }^{7}$

\section{BÜYÜK SELÇUKLU (İRAN SELÇUKLULARI) PARALARININ GENEL ÖZELLIKLERİ}

A-Büyük Selçuklu sikkelerinin ön yüzlerinde görülen ana özellikler:

1-Kelime-î Tevhid ${ }^{8}$

2-Zamanın Halifesinin adı (Örnek: El-Kaaim Bi Emrillah)

3-Paranın birimi ${ }^{9}$ ( El-Dinar veya El-Dirhem)

4-Sikkenin basım yeri ve tarihi (Arapça)

Örnek: Hicri 481 y1lında Berdesir șehrinde basılan bir sikke

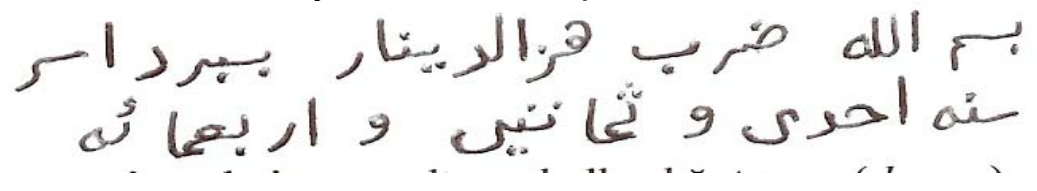

5-Ok ve yay işaretleri veya sultanın kullandığ $\operatorname{tamga~(damga)}$

\section{Örnek:}

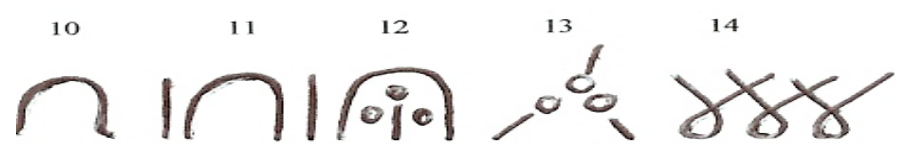

6-Diş çevrede Kur'an'dan bir ayet. ${ }^{10}$

7- Bu ayetler,sadece Sultan Sancar'a ait bazı sikkelerin ön yüzlerinin üst kısmındadır. ${ }^{11}$

${ }^{7}$ Ahmed Tevhid.Meskûkât-1 Kadim-i İslamiye Kataloğu.4. kısım.İstanbul,1321.s.6-38

8 Selçuklu paralarının ön yüzlerinin üst kısmında "Lâ İlahe İllallah Vahdehü Lâ şerike leh" yazılıdır.

9 Paranın birimi yazılırken:"Bismillah durube hazal dinar (veya dirhem) şeklinde yazılırdl.

${ }^{10}$ Selçklu paralarının ön yüzlerinin dış çevrelerinde,Kur'an'dan Rum Suresi (XXX.) 3.4. ayetleri yazılıdır.Ayetlerin Türkçe mealleri şöyledir:"Bundan önce de sonra da buyruk Allah'ındır.ve işte o gün mü'minler (Allah'ın) yardımına sevinecekler.Allah dilediğine yardım eder.O çok üstündür,çok güçlüdür, çok merhamet sahibidir" 
Büyük Selçuklu sultanlarından Sancar'ın paralarında,bu işaret ve bilgilerden farklı olarak Kur'an'dan Bakara Suresi (II.) nin 255. ayetinin (Ayet'elKürsî) bir bölümü yazılıdır.

B-Büyük Selçuklu sikkelerinin arka yüzlerinde mevcut olan özellikler:

1-Kelime-î Tevhid'in ikinci kısmı ${ }^{12}$

2-Sultanın unvanları lakâpları ve ismi.

\section{Örnek:}

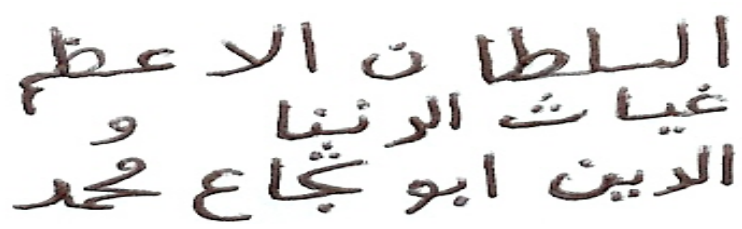

3- Dış çevrede Kur'an'dan bir ayet. ${ }^{13}$

Selçuklu paralarına Kur'an ayetleri yazma geleneği,Abbasîlerden Samanoğullarına ve onlardan da Selçuklulara geçmiştir.Bu konuda,Selçuklu yönetiminde görev alan,İran kökenli devlet adamlarının rolü önemlidir.Gaznelilere ait paralarda Kur'an ayetleri bulunmamaktadır. ${ }^{14}$

C-Selçuklu Sultanları,bazı özel günler ve zaferlerin anısına,farklı paralar ve madalyonlar kestirmişlerdir.

Örnek: Sultan Alp Arslan'ın H.461 yılında Merv'de kestirdiği dinarda," Esmâ-ı Hünsâ"’ denilen, Allah'ın 99 ismi yazılıdır ${ }^{15}$.(Resim-1)

\footnotetext{
${ }^{11}$ Sultan Sancar'ın H.490? da ,basim yeri silik sikkesi.

${ }^{12} \mathrm{Bu}$ kısımda “Muhammed'un Resulallah" yazılıdır.

${ }^{13}$ Selçuklu paralarının arka yüzlerinin dış çevresinde Kur'an'dan Tevbe Suresi'nin (IX.) 33. ayeti yazılıdır. Ayetin Türkçe meali şöyledir:"O Allah ki müşrikler hoşlanmasa da istemese de dinini bütün dinlerden üstün kllmak için Peygamberlerini doğru yol ve hak din ile göndermiştir."

${ }^{14}$ Ahmet Tevhid.Meskûkât-1 Kadim-î İslâmiye Kataloğu İstanbul 1321.s.38-52

${ }^{15} \mathrm{Bu}$ sikke muhtemelen 1068 yılında yapılan II.Kafkasya seferindeki başarıların anısına basılmıştır.
} 


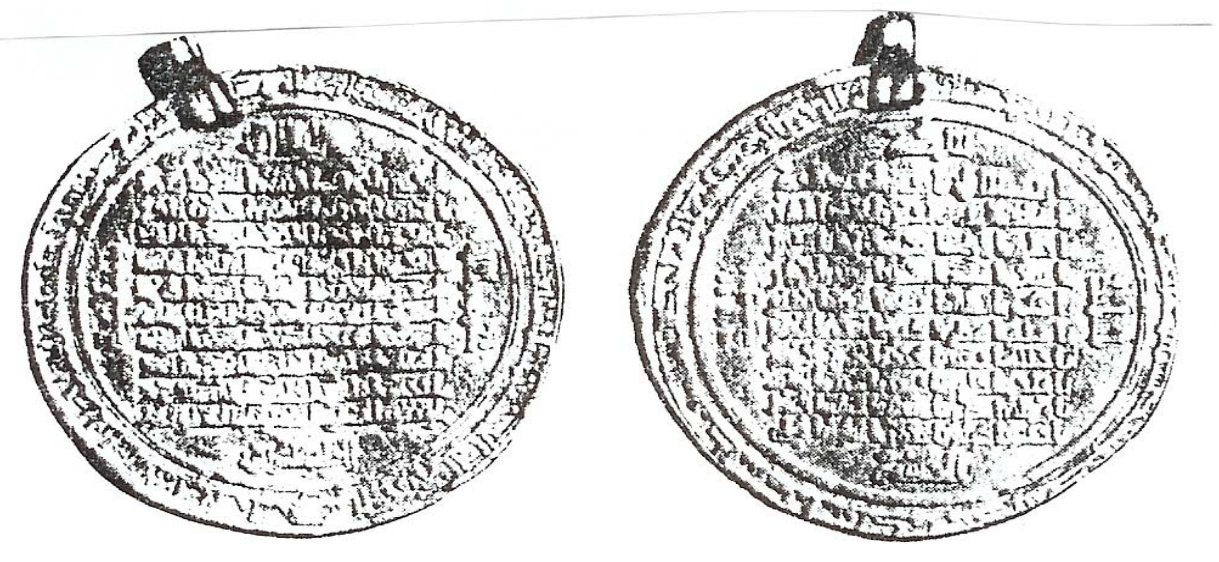

Resim-1) Büyük Selçuklu Sultanı Alp Arslan'nın Esmâ-ıHüsna yazılı dinarı

Buna benzer bir diğer sikke,Sultan Tuğrul Bey tarafindan bastırılan H.455 (M.1063-64) tarihli madalyondur.Medinetü's-Selam (Bağdat) da kesilen bu madalyon $45 \mathrm{~mm}$. Çapında ve 18.70 gram ağırlıktadır.Paranın ön yüzünde,bağdaş kurmuş bir hükümdar tasviri,iki yandaki boşluklarda,basım yeri ve basım tarihi yazılıdır.Bu para,günümüzde de önemli günlerin anısına bastırılan paralar gibi özel bir para olup,sınırlı sayıdadır. ${ }^{16}$ (Resim-2)

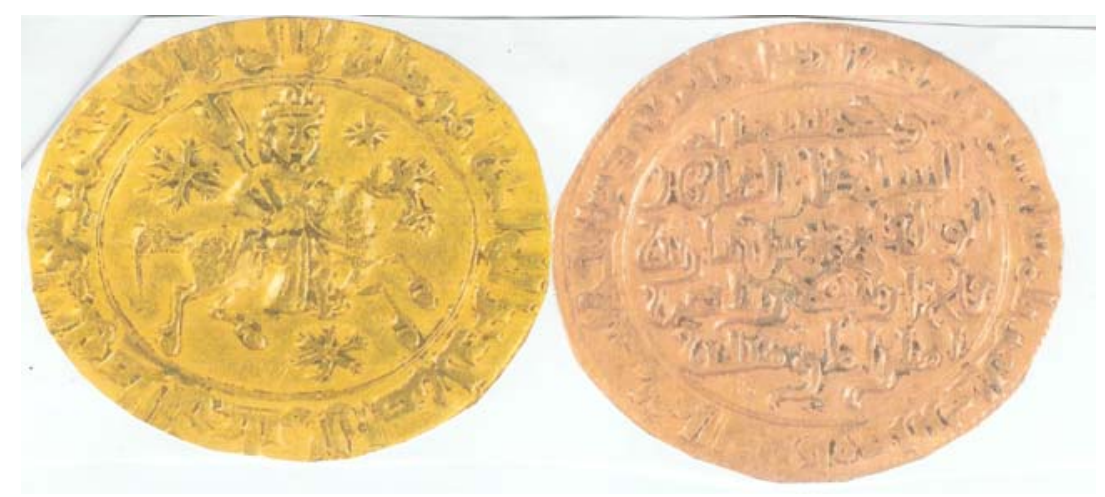

(Resim-2) Altın madalyon.Tuğrul Bey.Medinetü'-Selam (Bağdat)H.455 (M.1063-64)

16 Tuğrul Bey'in madalyonunda görülen ,bağdaş kurmuş hükümdar tasviri, Hunlarda, Göktürklerde ve Kuşanlarda sık rastlanan eski bir Türk geleneğidir. 
Büyük Selçuklu Sultanlarına ait bir paranın,ön ve arka yüzlerinde bulunan yazılar,figürler ve bilgileri,örnek bir parada göstermek mümkündür:

Örnek: Tuğrul Bey'e ait H. 453 yllında Rey şehrinde basılan dinar. (altın, $20 \mathrm{~mm} .4 .1$ gram)

\section{ÖN YÜZ}

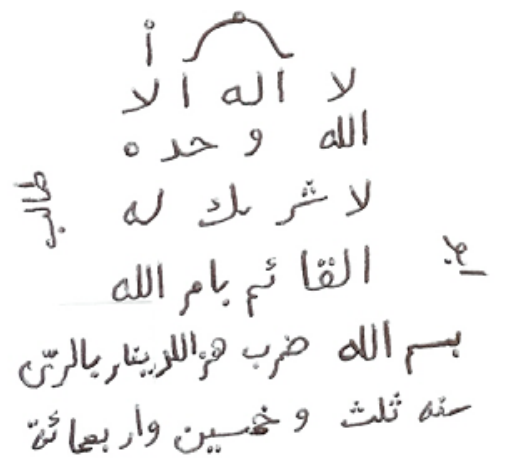

Diş Çevre Kur'an XXX,3-4

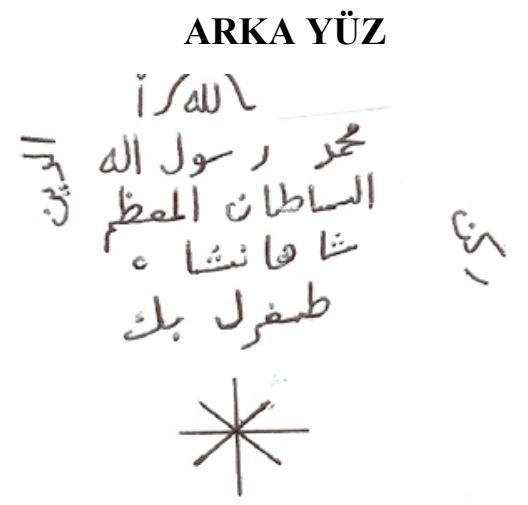

Dış Çevre Kur'an IX.,33

\section{II- ANADOLU (Türkiye/Rum) SELÇUKLU PARALARININ BÜYÜK SELÇUKLU PARALARINDAN FARKLI ÖZELLİKLERİ}

Büyük Selçuklu Sultanları ile aynı aileden gelen Anadolu Selçuklu Sultanları,farklı dil,inanç ve kültürlere sahip,yabancı bir ülkede egemenlik kurmuşlardi.

Türkler Anadolu'da Rum,Ermeni ve Süryani toplulukları ile bir arada yaşadılar.Büyük Selçuklulardan farklı olarak Bizans,Trabzon Rum İmparatorluğu ve Kilikya Ermeni Krallığ 1 ile yakın komşu oldular.

Bu yeni ortamın doğal bir sonucu olarak,Müslüman olmayan bu farklı kültür ve medeniyetlerden etkilendiler.Bu etki, devlet teşkilat1,sosyal ve kültürel yaşamda olduğu kadar;paralarda da görülür.

Bunun en belirgin örneği,daha önce sadece özel madalyonlarda görülen resimlerin (tasvirler) Anadolu Selçuklu sikkelerini,hemen hemen tamamında kullanılmasıdır. 
Anadolu Selçuklu Sultanlarının ilk ikisi (I.Rükneddin Süleymanşah ve I.Kılıç Arslan) ne ait herhangi bir sikke bulunamamıştır. ${ }^{17}$

Anadolu Selçuklu sultanlarından sikkesi bulunan ilk hükümdar,sultan I.Mesut'tur.Basım yeri ve basım tarihi silinmiş olan bu sikke hakkında Ahmed Tevhid,eserinde şu açıklamaları yapmaktadır. ${ }^{18}$

"Bizantin imparatoru tarzinda bir nim tasvir" bulunmakta ve "Imparator Birinci AleksisKomnenos meskêkâtına müşabihtir" ${ }^{19}$ Aynı sikke, 1994 yılında yayınlanan bir katalogda, (muhtemelen yanlış okumadan kaynaklanan bir nedenle) yanlış şekilde yorumlanmış ve şu ifadelere yer verilmiştir:

"Ön yüzünde Bizans Imparatoru I.Alexius Comnenus'n tasviri" bulunmaktadır. $^{20} \quad \mathrm{Bu}$ şekilde bir yorum,tarihi gerçekleri yansıtmamaktadır.Çünkü böyle bir uygulama,(Anadolu Selçuklu parasında Bizans Imparatorunun resminin bulunması) bağımlılık anlamına gelir .

Sultan I.Mesud'un (1116-1155) bakır sikkesi: ${ }^{21}$ (Resim-3)

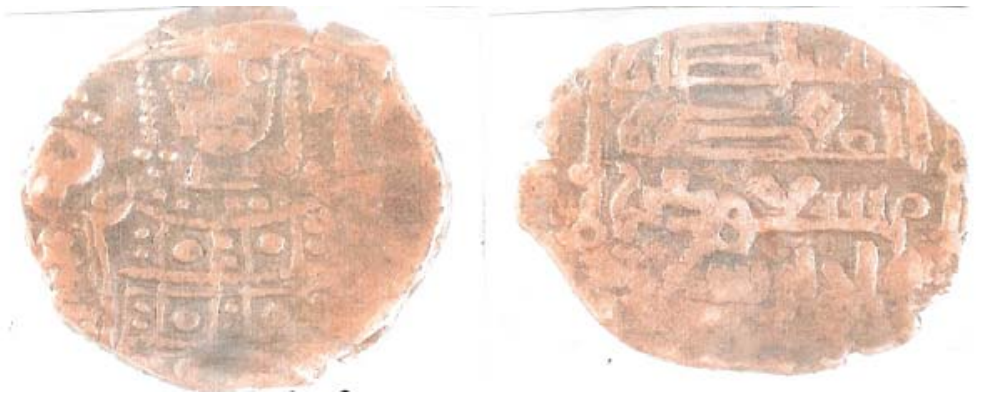

Resim -3

Mesud I.Bakır, ,H.510-551-- M.1116-1155 (22 mm.,4.25 gr.)

\footnotetext{
${ }^{17}$ İlk iki Anadolu Selçuklu Sultanlarının para bastırmamaları,siyâsî anlamda,tam bağımsızlık kazanamamalarına bağlanabilir.Çünkü I.Süleyman Şah(Kutalmışoğlu)1086 ve I.Kılıç Arslan,1107 yıllarında Büyük Selçuklular ile yaptıkları egemenlik mücadelesinde hayatlarını kaybettiler.Bu dönemde Anadolu egemenliğinde,Büyük Selçuklulara bağımlı Danişmendliler ilk sıradadırlar.

${ }^{18}$ Ahmed Tevhid,Meskûkât-ı Kadim-i İslâmiye Kataloğu Cilt 4,s.108

$19 \mathrm{Bu}$ ifadeler,Anadolu Selçuklu paralarında Bizans etkilerinin örneğidir.Ahmed Tevhid.a.g.e.s. 108

${ }^{20}$ Yapı Kredi Sikke koleksiyonu Sergileri.C.2.s.22.res.9.

${ }^{21}$ Yapı Kredi Sikke Koleksiyonu.C.2.No:8202,s.22
} 
Sikkenin basım yeri ve basım tarihi siliktir.Ön yüzünde,Bizans İmparatoru I.Alexius Comnenus'un paralarındaki portrelere benzeyen bir yarım portre,arka yüzünde; "Essultan el-muazzam,Mes'ud bin Kılıç Arslan” yazilidir.

Üzerinde resim bulunan (tasvirli) Anadolu Selçuklu sikkelerinden bazıları şunlardır:

1-Sultan Gryaseddin Keyhusrev I'e (I.saltanatı 1192-1196 /II. Saltanatı, 1204-1211) ait üç adet bakır sikke. ${ }^{22}$

2- Rükneddin Süleyman Şah II 'nin,Tokat Meliki olduğu zaman kestirdiği iki bakır sikke. $^{23}$

3-II.Kılıç Arslan'ın oğullarından Malatya Meliki Kayserşah'a ait bakır sikke. ${ }^{24}$

4-Sultan Rükneddin Süleyman Şah II.'nin, H.597 (M.1201) de Konya'da kestirdiği altın sikke ${ }^{25}$.(resim-4)

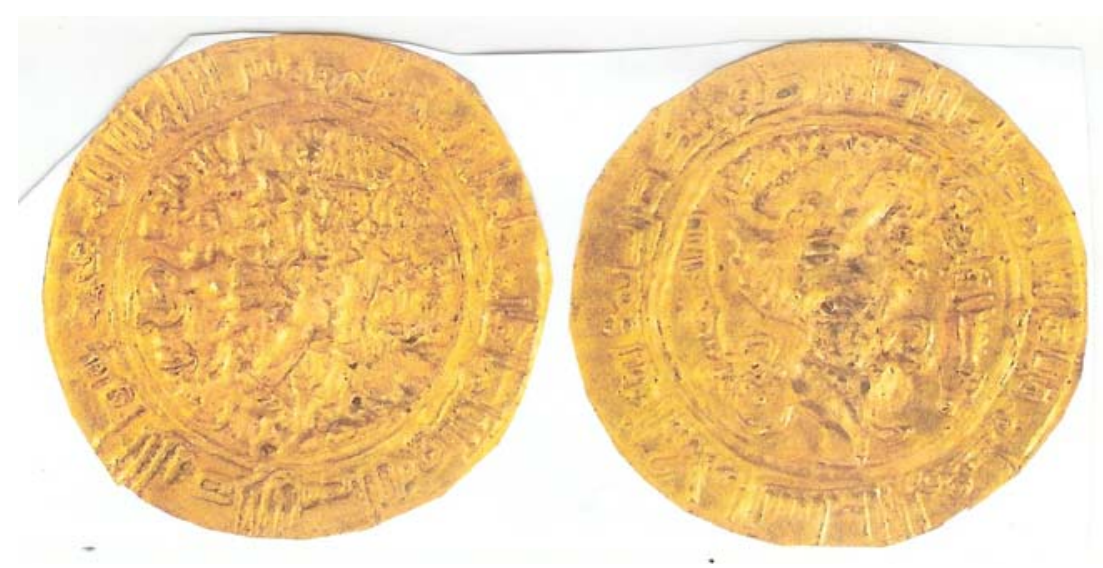

Resim - 4

\footnotetext{
${ }^{22}$ Yap1 Kredi Koleksiyonu C.2,No:8277,8282,8290.s.24

${ }^{23}$ Yap1 Kredi Koleksiyonu.C.2.No:8313,8314.s.25

${ }^{24}$ Yap1 Kredi Koleksiyonu.C.2.No:8325.s.25

${ }^{25}$ Yap1 Kredi Koleksiyonu.C.2.No:8355.s.26-27
} 
Resimde görülen bu sikkenin ön yüzünde,II.Süleyman şah'a ait bir süvari tasviri,çevrede ise,"Kelime-î Tevhid" bulunmaktadır.Görüldüğü gibi bu yüzde,Büyük Selçuklu paralarında bulunan "Rum Suresi'nin 3.4. ayetleri" yoktur.

Sikkenin arka yüzünde ise,ortada sultanın unvanları ve ismi,çevrede ise "Tevbe Sûresinin 33.ayeti” bulunmaktadır.

5-Sultan Giyaseddin Keyhusrev II.'ye ait H.640 (M.1242-43) Sivas'ta kesilen gümüş dirhem. ${ }^{26}$ (Resim-5) (23 mm.,2.74 gr.) (Resim-5)
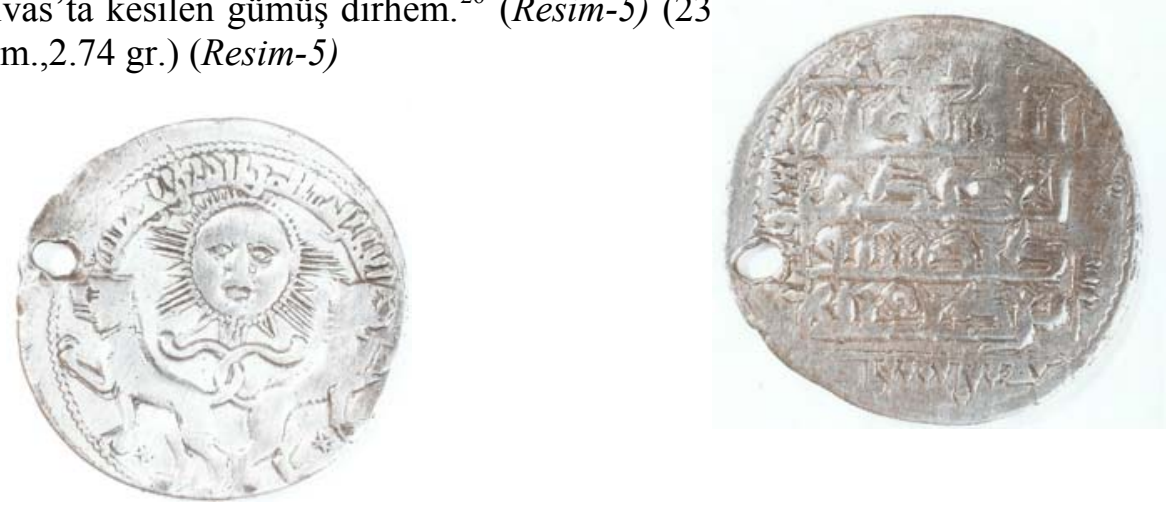

Resim-5 Ön yüz:Ortada Hurşid (Güneş) Arka yüz:Halifenin ve Sultanın Altında iki aslan ve aslanların ayakları Arasında * işaret vardır. isim ve unvanları ile paranın Basım yeri ve tarihi yazılıdır

Anadolu Selçuklu paralarında,Büyük Selçuklu paralarından farklı olan birtakım özellikleri,şöyle sıralamak mümkündür:

a- $\quad$ Sikkelerin üzerindeki yazılar,kavisli daireler veya kare çerçeveler ile kuşatılmıştır.

b- Sikkelerin basim yerleri,basim tarihleri ve birimler (dinardirhem),paranın diş çevresindeki boşluklara serpiştirilmiş̧tir.

c- Bazl sikkelerde,paranın basım yeri yazılırken,başlangıcına besmelenin tamamı (Bismillahi- rahman-i'rrahim),bazılarında ilk kısm (Bismillah) yazılırken:bazılarında Besmele hiç yazılmamıştır.

d- I.Glyaseddin Keyhusrev'in ikinci saltanatı (1204-1211) esnasinda kesilen paralar ${ }^{27}$ ile;II.Izzeddin Keykâvus'un oğlu olup Cimri unvanı ile

\footnotetext{
${ }^{26}$ Yap1 Kredi Koleksiyonu.C.2.No:8940,s.38-39

${ }^{27}$ Ahmet Tevhid.a.g.e.s.138.(Bu ifadenin anlamı:Minnet ancak Allah içindir)
} 
meşhur olan Alâeddin Siyavuş'un Konya'da kestirdiği iki sikkede 28 "ElMinnetullah” ifadesi kullanılmış, bu ifade sonraları yaygınlaşmıştır.

e- Anadolu Selçuklu paralarının bir kısmında,Büyük Selçuklu paralarının ön ve arka yüzlerinin dış çevrelerinde görülen Kur'an ayetleri yoktur.(Ön yüzde Rum Suresi/XXX.'nin 3.4.ayetleri ve arka yüzlerinde,Tevbe Sûresi/IX. 'nin 33.ayeti vardl)

f- $\quad$ Büyük Selçuklu sultanları bakır sikke kestirmediler.(Büyük Selçuklu paraları çoğunlukla altın ve bir kısmı gümüştür) Anadolu Selçuklu sultanları ise çok sayıda bakır sikke kestirdiler.

g- Büyük Selçuklu sikkelerinin çoğunda görülen “ok ve yay”(Kınık Boyu'nun tamgas1), Anadolu Selçuklu sikkelerinde görülmemektedir. Anadolu Selçuklu sikkelerinde çok yaygın olarak * ve az olarak da gibi - - işaretler bulunmaktadir.

h- Bir çok Anadolu Selçuklu sikkesinde, Güneş (Hurşid) ile tek veya çift aslan motifleri bulunur. ${ }^{29}$

i- Anadolu Selçuklu Devleti'nde ilk defa bir "Müssterek Para" uygulamasi görüldü H.653. (M-1255-1256) da kesilen altın, para, müşterek sikke uygulamasının ilk örneklerindendir.(Resim-6)
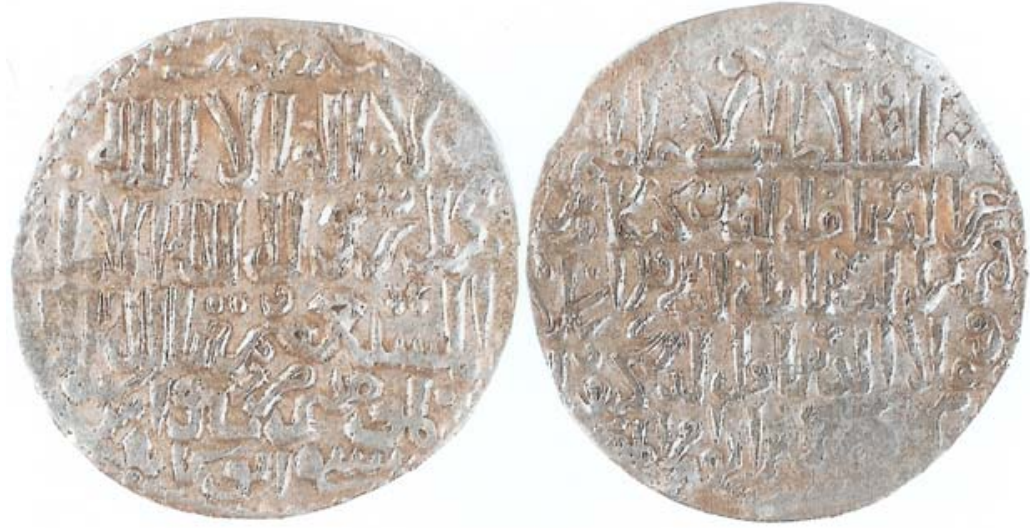

\section{Resim-6}

Anadolu, 1243 Kösedağ savaşından sonra,büyük ölçüde Moğol egemenliği altına girdi.Moğol yönetimi,siyâsî alandaki baskılarının yanı sıra,ekonomik

\footnotetext{
${ }^{28}$ Yap1 Kredi Koleksiyonu.C.2.No: 9626,9627.

${ }^{29}$ II.Gryaseddin Keyhusrev'e ait Konya ve Sivas'ta kesilen 1241-42,ve 1242-43 tarihli sikkeler.
} 
alanda da olumsuz etkilerin sergiledi.Anadolu Selçuklu Devleti'nde toprak yönetiminin özünü oluşturan "íktâ" sistemi, Moğol istilası sonunda dağ 1 ld1.Ekonominin ve sosyal dengenin en önemli unsuru olan bu sistemin bozulması,gelir ve ürünlerin azalmasına ,bu da toplanan vergilerin eksilmesine neden oldu. Bekledikleri vergi gelirlerini sağlayamayan Moğollar,eksikleri gidermek için baskı ve yağmaları arttırdılar. ${ }^{30}$ Moğol egemenliğine karşı ilk tepkiler,Anadolu'nun güçlü Türkmen aşiretlerinden Karamanoğulları ve Germiyanlılar'dan geldi Mısır Memlük Hükümdarı Sultan Baybars'ın Moğollara karşı kazandığı zaferler,Anadolu'da Moğol baskısını azalttı. Bu baskı, İslamiyetin Moğollar arasında yayılması ile daha da azalacaktır.

Böyle bir ortamda, Moğollara bağlı ,kukla bir yönetimi temsil eden,Anadolu Selçuklu Hanedanı'nın saygınlığı kalmamıştı.Türkmen grupları Anadolu'nun çeşitli yörelerinde bağımsız beylikler kurmaya başladılar."Tevaîf-î Mülûk" adı verilen bu beyliklerin sayıları giderek çoğaldı.Beyliklerin siyâsî yapıları ile kültür ve medeniyetleri,Anadolu Selçuklu Devleti'nin devamı şeklinde olmuştur. Aynı şekilde,beyliklerde basılan sikkeler,Anadolu Selçuklu sikkelerini andırır.Moğol etkilerini,beyliklerin sikkelerinde görmüyoruz.Bu beyliklerden birisi olan Osmanlı Beyliği, XIII.Y.Y.sonunda ortaya çıkarak,Anadolu Türklüğünü yeniden birleştirecek,siyâsî ve kültürel birliği sağlamaya muvaffak olacaktır.

\section{KAYNAKLAR}

AKDAĞ, Mustafa. Türkiye'nin İktisadi ve İçtimai Tarihi, C.I. İstanbul 1995.

ALPTEKİN, Coşkun, Selçuklu Paraları (Makale), Selçuklu Araştırmaları Dergisi, C.III. Ankara. 1971.

ESIN, Emel, İslamiyetten Önce Türk Kültür Tarihi ve İslama Giriş. İst 1978.

LITVINSKY, B.A. "History of Civilization of Central Asia" Vol.III, Ed. Unesco. 1976.

TEVHIDD, Ahmed, "Meşkulat-1 Kadim-i İslamiye Kataloğu, İst 1321.

TURAN, Osman. Selçuklular Zamanında Türkiye Tarihi, İstanbul. 1971.

Yap1 Kredi Sikkeler Koleksiyonu C.2

\footnotetext{
${ }^{30}$ Kaynaklara göre, Kösedağ öncesinde yıllık 36.000.000 altın olan Anadolu vergi gelirleri, Kösedağ' dan sonra yıllık 3.600 .000 altına düşmüştür. (Osman Turan,Selçuklular Zamaninda Türkiye Tarihi)
} 
A.Ü. Türkiyat Araştırmaları Enstitüsü Dergisi Sayı 29 Erzurum 2006 195 Prof. Dr. Zeki Başar Özel Sayısı

TAED 29, 2006, 183-194 